\title{
Activation of spleen cells by ArtinM may account for its immunomodulatory properties
}

\author{
Thiago Aparecido da Silva • Maria Aparecida de Souza • \\ Nerry Tatiana Cecílio $\cdot$ Maria Cristina Roque-Barreira
}

Received: 15 August 2013 / Accepted: 24 March 2014 /Published online: 20 May 2014

(C) The Author(s) 2014. This article is published with open access at Springerlink.com

\begin{abstract}
ArtinM is a D-mannose-binding lectin extracted from Artocarpus heterophyllus that promotes interleukin-12 production by macrophages and dendritic cells. This property is considered responsible for $\mathrm{T}$ helper 1 immunity induced in vivo after ArtinM administration. In this study, we investigated the effect of native (jArtinM) and recombinant (rArtinM) forms of lectin on murine spleen cells and isolated T lymphocytes. We found that ArtinM binds to the surface of spleen cells. This interaction, which was blocked by Dmannose, induced cell activation, as manifested by increased mitochondrial activity, interleukin-2 production, and cell proliferation. We verified that a 30-times higher concentration of rArtinM was required to trigger optimal activation of spleen cells compared with that needed with jArtinM, although these proteins have identical sugar recognition properties and use the same signaling molecules to trigger cell activation. Because the distinction between native and recombinant is restricted to their tertiary structure (tetrameric and monomeric, respectively), we postulated that the multi-valence of jArtinM accounts for its superiority in promoting clustering of cell surface glycoreceptors and activation. The jArtinM and rArtinM activation effect exerted on spleen cells was reproduced on purified $\mathrm{CD} 4^{+} \mathrm{T}$ cells. Our results suggest that ArtinM interaction with $\mathrm{T}$ cells leads to responses that may act in concert with the interleukin-12 produced by antigenpresenting cells to modulate immunity toward the T helper 1 axis. Further studies are necessary to dissect ArtinM/T-cell interactions to more fully understand the immunomodulation induced by carbohydrate recognition.
\end{abstract}

T. A. da Silva $\cdot$ M. A. de Souza • N. T. Cecílio •

M. C. Roque-Barreira ( $\square)$

Departamento de Biologia Celular e Molecular e Bioagentes Patogênicos, Faculdade de Medicina de Ribeirão Preto, Universidade de São Paulo, Avenida Bandeirantes 3900, 14049-900 Ribeirão Preto, SP, Brazil

e-mail: mcrbarre@fmrp.usp.br
Keywords ArtinM · Spleen cells · T lymphocytes · Carbohydrate recognition $\cdot$ Immunomodulation

\section{Introduction}

Lectins are proteins with at least one non-catalytic domain that binds reversibly and specifically to a mono- or oligosaccharide (Peumans and Van Damme 1995). They are ubiquitous in nature, being found in organisms from viruses to humans (Sharon 2008). Lectins are involved in numerous biological activities, including promotion of cell-cell and cell-extracellular matrix interactions, complement system activation, induction of leukocyte activation and migration, induction of cytokine production, adhesion of pathogens to host cells, and induction of cell death (Sharon and Lis 2004). Most often, the biological activities of lectins depend on their carbohydrate recognition domain (CRD), which interacts with cell surface glycoproteins (Baba et al. 2007) that trigger cell signaling.

ArtinM, a D-mannose-binding lectin, obtained from the seeds of Artocarpus heterophyllus, is organized as a homotetramer formed by 16-kDa non-glycosylated subunits (Santos-de-Oliveira et al. 1994). Each polypeptide chain contains a CRD with affinity to Man $\alpha$ 1-3 [Man $\alpha$ 1-6] Man, which corresponds to the core $\mathrm{N}$-linked oligosaccharides. The following activities are attributed to ArtinM: (1) neutrophil activation, triggered by binding to $\mathrm{N}$-glycans on Toll-like receptor 2 (TLR2) and chemokine receptor (CXCR2) (Ganiko et al. 1998; Pereira-da-Silva et al. 2006; Santos-deOliveira et al. 1994), (2) mast cell degranulation induced by interactions with $\mathrm{N}$-glycans of Fc\&R or N-glycans of immunoglobulin E-linked FceR (Moreno et al. 2003), and (3) production of interleukin (IL)-12 stimulated by recognition of $\mathrm{N}$-linked glycans of the TLR2 ectodomain on the surface of macrophages and dendritic cells (Coltri et al. 2008). The induction of IL-12 production is considered a central effect 
because ArtinM administration drives immunity toward the $\mathrm{T}$ helper (Th) 1 axis (Panunto-Castelo et al. 2001; Teixeira et al. 2006), conferring resistance to infections by intracellular pathogens such as Leishmania major (Panunto-Castelo et al. 2001), L. amazonensis (Teixeira et al. 2006), Paracoccidioides brasiliensis (Coltri et al. 2008, 2010), Neospora caninum (Cardoso et al. 2011), and Candida albicans (Custodio et al. 2011).

The ArtinM immunomodulatory property is exerted by both lectin forms, native (jArtinM) and recombinant (rArtinM) (daSilva et al. 2005; Pranchevicius et al. 2012), which structurally differ in terms of oligomerization. In opposition to the tetrameric structure of native ArtinM, the recombinant counterpart, obtained by expression in Escherichia coli, is monomeric. The availability of native and recombinant ArtinM provides convenient tools with which to investigate the requirements for triggering cell signaling.

Regarding the mechanisms accounting for ArtinM immunomodulatory properties, IL-12 production due to lectin interaction with TLR2 on macrophages and dendritic cells has been well exploited. However, the possibility that the effects of ArtinM extend to lymphoid cells and establish interactions that contribute to immunomodulation has not been investigated. In the present study, the activities exerted by native and recombinant ArtinM on murine spleen cells were examined. A direct effect on $\mathrm{T}$ cells was verified, providing new elements for full comprehension of the immunomodulation promoted by ArtinM and its potential application to the design of immunotherapeutic strategies.

\section{Materials and methods}

\section{Ethics statement}

Animal studies were approved by the Ethical Committee of Ethics in Animal Research of the College of Medicine of Ribeirão Preto of the University of São Paulo and were conducted in accordance with the Ethical Principles in Animal Research adopted by the Brazilian College of Animal Experimentation, Protocol no. 082/2012.

\section{Animals}

Male BALB/c, C57BL/6, TLR2 KO, and TLR4 KO mice were acquired from the animal house of the Campus of Ribeirão Preto, University of São Paulo, Ribeirão Preto, São Paulo, Brazil, and housed in the animal facility of the Molecular and Cellular Biology Department of the Faculty of Medicine of Ribeirão Preto, University of São Paulo, under optimized hygienic conditions. All experiments were conducted in accordance with the ethical guidelines of the animal studies ethics committee. The experimental mice were used at 6-8 weeks of age.

Lectins

jArtinM was purified as previously described (Santos-deOliveira et al. 1994) from the saline extract of A. heterophyllus (jackfruit) seeds via affinity chromatography on sugar columns. rArtinM was expressed in E. coli BL21 and purified as previously reported (daSilva et al. 2005). Before use, preparations of jArtinM and rArtinM were incubated for $1 \mathrm{~h}$ with polymyxin solution (Sigma-Aldrich, St. Louis, MO, USA). Concanavalin A (ConA) from Canavalia ensiformis was purchased from Sigma Chemical.

Suspensions of spleen cells and isolated $\mathrm{CD}^{+} \mathrm{T}$ cells

Mice spleens were removed aseptically and transferred to a Petri dish where they were soaked and filtered in a 40- $\mu \mathrm{m}$ nylon cell strainer (BD Biosciences, San Diego, CA, USA) containing Roswell Park Memorial Institute (RPMI) 1640 medium. The cellular suspension was centrifuged at $300 \mathrm{~g}$ (10 min at $4{ }^{\circ} \mathrm{C}$ ) to yield a pellet. The suspension was erythrocyte-depleted with lysing buffer ( 9 parts $0.16 \mathrm{M}$ ammonium chloride and one part $0.17 \mathrm{M}$ Tris- $\mathrm{HCl}, \mathrm{pH} 7.5$ ) for $10 \mathrm{~min}$ at $4{ }^{\circ} \mathrm{C}$. The spleen cells were then washed twice in $10 \%$ fetal cow serum (FCS)/RPMI 1640 and centrifuged at $300 \mathrm{~g}$ (10 min at $\left.4{ }^{\circ} \mathrm{C}\right)$. Cells were counted in a Neubauer chamber, and their viability was determined using the trypan blue exclusion method. Viability of the spleen cells was greater than $90 \%$.

$\mathrm{CD}^{+} \mathrm{T}$ cells were isolated from spleen cell suspensions using $\mathrm{CD}^{+}{ }^{+} \mathrm{T}$ cell isolation kits II and MS columns, both from Miltenyi-Biotec (Auburn, CA, USA) according to the manufacturer's instructions. To assess purity, negatively selected cells were stained with anti-CD4 PE-Cy5 antibody (BD Biosciences) and analyzed with flow cytometry (Guava easyCyte, Guava Technologies, Millipore). Purity grades of 92-95\% were achieved.

\section{IL-2 measurement in cell supernatants}

Spleen cells $\left(1.5 \times 10^{6} / \mathrm{mL}\right)$ were cultured in the presence of jArtinM (0.14-156.00 nM), rArtinM (0.56-625.00 nM) or ConA (49.0 nM) in 96-well microplates. After 12, 24, 48, and $72 \mathrm{~h}$ of incubation, the spleen cells were centrifuged $(300 \mathrm{~g}, 10 \mathrm{~min}$ at room temperature), and the supernatants were collected to measure IL-2 levels using an enzymelinked immunosorbent assay from Kit OptEIA (BD Biosciences) according to the manufacturer's instructions. Similar procedures were performed to determine IL-2 levels in the supernatants of isolated $\mathrm{CD}^{+} \mathrm{T}$ cells. 
3-(4,5-dimethyl-thiazol-2-yl)-2,5-diphenyltetrazolium bromide (MTT) assay

Spleen cells distributed and stimulated as described for IL-2 detection were assayed for the reduction of MTT (SigmaAldrich) and production of formazan crystals (Mosmann 1983). MTT solution $(500 \mu \mathrm{g} / \mathrm{mL}$ in RPMI 1640 containing $10 \%$ FCS $)$ was added $(100 \mu \mathrm{L})$ to the wells containing spleen cells. The microplates were incubated for $3 \mathrm{~h} 30 \mathrm{~min}$ at $37^{\circ} \mathrm{C}$ in a humidified atmosphere of $5 \% \mathrm{CO}_{2}$. The cells were then centrifuged $(300 \mathrm{~g}, 10 \mathrm{~min}$ at room temperature), the supernatants were removed, and $100 \mu \mathrm{L}$ dimethyl sulfoxide was added to the wells. After overnight incubation at room temperature, the absorbance was read at $570 \mathrm{~nm}$ using a spectrophotometer (Power Wave X; BioteK Instruments). Mitochondrial activity was expressed as absorbance variation (as a percentage) in relation to the negative control and calculated as follows: [(optical density value in stimulated cells/ average optical density value in unstimulated cells) -1$] \times 100$. The positive or negative percentage values represent the increase or decrease in mitochondrial activity related to unstimulated cells.

\section{Cell proliferation assay}

Spleen cells $\left(1.5 \times 10^{6} / \mathrm{mL}\right)$ were distributed in a $96-$ well microplate and cultured in the presence of jArtinM $(2.25 \mathrm{nM}$ or $4.50 \mathrm{nM})$, rArtinM (78.00 $\mathrm{nM}$ or $156.00 \mathrm{nM})$, or ConA $(24.5 \mathrm{nM})$. The cells were cultured for $48 \mathrm{~h}$, and, during the last $12 \mathrm{~h}$ of incubation, tritiated thymidine $([3 \mathrm{H}]-\mathrm{TdR}$; Amersham Bioscience, Boston, MA, USA) was added to the wells $(0.5 \mu \mathrm{Ci} /$ well). Cell proliferation was assessed by measuring $[3 \mathrm{H}]-\mathrm{TdR}$ incorporation, and the results were expressed in counts per minute (cpm).

\section{Sugar inhibition assay of ArtinM activities}

D-mannose $(100 \mathrm{mM})$ or D-galactose $(100 \mathrm{mM})$ was added to jArtinM $(2.25 \mathrm{nM})$, rArtinM $(78.00 \mathrm{nM})$, or phorbol myristate acetate (PMA; $81.0 \mathrm{nM})$ plus ionomycin $(1.0 \mu \mathrm{M})$. After 30 min of incubation at $4{ }^{\circ} \mathrm{C}$, the mixtures were distributed in the wells of a microplate containing spleen cell suspension $\left(1.5 \times 10^{6} \mathrm{cell} / \mathrm{mL}\right)$ in a final concentration of $50 \mathrm{mM}$ sugars. The microplates were incubated at $37{ }^{\circ} \mathrm{C}$ in a humidified atmosphere of $5 \% \mathrm{CO}_{2}$. The cells and supernatants were analyzed for mitochondrial activity and IL-2 levels following the protocols described earlier.

Cell activation after treatment with inhibitors of cell signaling molecules

Spleen cells $\left(1.5 \times 10^{6} / \mathrm{mL}\right)$ were incubated with the protein tyrosine kinase inhibitor genistein $(20 \mu \mathrm{g} / \mathrm{mL})$, the p42/44 mitogen-associated protein kinase (MAPK) inhibitor PD98059 $(20 \mu \mathrm{M})$, the p38 MAPK inhibitor SB202190 $(20 \mu \mathrm{M})$, the protein kinase $\mathrm{C}$ inhibitor H-7 $(20 \mu \mathrm{M})$, or the c-Jun N-terminal kinase (JNK) inhibitor SP600125 $(25 \mu \mathrm{M})$ for $3 \mathrm{~h} 30 \mathrm{~min}$ in RPMI 1640 with $10 \% \mathrm{FCS}$ at $37^{\circ} \mathrm{C}$ in a humidified atmosphere of $5 \% \mathrm{CO}_{2}$. The cells were then stimulated with jArtinM $(2.25 \mathrm{nM})$, rArtinM $(78.00 \mathrm{nM})$, PMA $(81.0 \mathrm{nM})$ plus ionomycin $(1.0 \mu \mathrm{M})$, or ConA $(49.0 \mathrm{nM})$ for $48 \mathrm{~h}$. The cells and supernatants were analyzed for mitochondrial activity and IL-2 levels following protocols described earlier.

Flow cytometry analysis of ArtinM binding on spleen cells

Biotinylated ArtinM $(20 \mu \mathrm{g} / \mathrm{mL})$ was incubated for $45 \mathrm{~min}$ with D-mannose or D-galactose $(1 \mathrm{mM}, 10 \mathrm{mM}, 20 \mathrm{mM}$, $30 \mathrm{mM}$, or $50 \mathrm{mM}$ ) or with medium alone. These mixtures were added to fixed ( $3 \%$ formaldehyde-phosphate-buffered saline) spleen cells $\left(1.5 \times 10^{6} / \mathrm{mL}\right)$ that were then incubated for $30 \mathrm{~min}$ at room temperature. After two washes with phosphate-buffered saline, bound biotinylated ArtinM on spleen cells was reacted with streptavidin-fluorescein isothiocyanate (strp/FITC; $5 \mu \mathrm{g} / \mathrm{mL}$; Invitrogen) for $40 \mathrm{~min}$ and fluorescence staining was analyzed with flow cytometry (Guava EasyCyte). The percentage of stained spleen cells was then determined. To evaluate ArtinM binding on T cells, we treated the spleen cells with bound ArtinM for an additional 40 min with anti-CD3 PE-Cy5 antibody $(4 \mu \mathrm{g} / \mathrm{mL}$; BD Biosciences) and performed flow cytometry analysis. The percentage of double-positive cells for each experimental condition was then analyzed.

Competition assays between an anti-CD3 antibody and ArtinM in relation to $\mathrm{CD}^{+} \mathrm{T}$ cells

The binding of ArtinM to $\mathrm{CD} 3$ receptor was determined on $\mathrm{CD}^{+} \mathrm{T}$ cells isolated from spleen cell suspensions using $\mathrm{CD}^{+} \mathrm{T}$ cell isolation kits II and MS columns from MiltenyiBiotec according to the manufacturer's instructions. In the first assay, the cells were fixed and incubated with ArtinM $(25 \mu \mathrm{g} /$ $\mathrm{mL}$ ) for $40 \mathrm{~min}$ at $4{ }^{\circ} \mathrm{C}$. After two washes with phosphatebuffered saline (PBS), the cells were incubated with an antiCD3 PE-Cy 5 antibody $(10 \mu \mathrm{g} / \mathrm{mL}$; clone $17 \mathrm{~A} 2$; BD Biosciences) for $40 \mathrm{~min}$ at $4{ }^{\circ} \mathrm{C}$. The percentage of labeled cells was determined using flow cytometry (Guava EasyCyte). A functional inhibition assay was carried out by pre-incubating $\mathrm{CD}^{+}$T cells with either the anti-CD3 antibody $(5 \mu \mathrm{g} / \mathrm{mL})$ or an anti-CD28 antibody $(5 \mu \mathrm{g} / \mathrm{mL}$; clone 37.51 ; BD Biosciences) for 40 min at $4{ }^{\circ} \mathrm{C}$. After washing with RPMI medium, the cells were stimulated for $48 \mathrm{~h}$ with jArtinM $(78 \mathrm{nM})$. The culture supernatants were tested by means of ELISA for IL-2. 


\section{Statistical analysis}

Results are presented as means \pm standard error of the mean and all data were analyzed using Prism (Graph Pad Software). Statistical determinations of the difference between means of groups were performed with analysis of variance (1-way) followed by Bonferroni's multiple comparison test. Differences that provided $p<0.05$ were considered statistically significant.

\section{Results}

ArtinM binding on murine spleen cells

The binding of ArtinM on murine spleen cells was evaluated by incubating the cells with biotinylated ArtinM $(20 \mu \mathrm{g} / \mathrm{mL})$ and reacting them with strp/FITC. Analysis with flow cytometry showed that approximately $90 \%$ of the cells were labeled (Fig. 1). The hypothesis that the ArtinM CRD could mediate binding on spleen cells led us to perform a sugar inhibition assay. Based on the known selectivity of ArtinM sugar recognition, D-mannose was used as an ArtinM ligand, and Dgalactose as a negative control. The proportion of ArtinMlabeled cells decreased in a dose-dependent manner when the lectin was preincubated with D-mannose, whereas Dgalactose had no effect on ArtinM binding on spleen cells (see Fig. 1). The binding was inhibited up to $85-88 \%$ when D-mannose concentrations varied from 20 to $50 \mathrm{mM}$, and was $50 \%$ inhibited by $10 \mathrm{mM}$. Otherwise, $1 \mathrm{mM}$ D-mannose or any D-galactose concentration tested had no significant effect on ArtinM binding to the spleen cell surface. These results suggest that glycans expressed on murine spleen cells are targeted by ArtinM.

Mitochondrial activity in murine spleen cells stimulated by jArtinM and rArtinM

To investigate whether the ArtinM interactions with glycotargets on the spleen cell surface trigger cell activation, we assessed the mitochondrial activity of ArtinM-stimulated spleen cells by performing MTT assay. Two different ArtinM preparations were tested. The first was jArtinM, which is the native tetrameric protein purified from jackfruit seeds. The other was rArtinM, the recombinant counterpart protein obtained from lectin expression in E. coli BL21 and characterized as monomeric. At varying concentrations $(0.1-625 \mathrm{nM})$, these preparations were used to stimulate spleen cell cultures for $12-72 \mathrm{~h}$.

Increased mitochondrial activity of spleen cells was mostly observed after 48 and $72 \mathrm{~h}$ of stimulation. jArtinM augmented mitochondrial activity when used at concentrations of 0.14 $9 \mathrm{nM}$, and maximum activity (closed to that provided by ConA, used as a positive control) was determined with
1.12-9 nM ArtinM (Fig. 2a). Stimulating similar mitochondrial activity required much higher concentrations of $\mathrm{rArtinM}$. Maximum activity was determined with $156 \mathrm{nM}$ rArtinM, which is a concentration 35 times higher than that of jArtinM required to induce the activity peak (Fig. 2b). No mitochondrial activity was detected when jArtinM concentrations were equal or superior to $18 \mathrm{nM}$, suggesting that high lectin concentrations may be toxic for the spleen cells (see Fig. 2).

\section{IL-2 production by spleen cells stimulated by jArtinM} and rArtinM

Because ArtinM binds to glycotargets on murine spleen cells and increases mitochondrial activity, we investigated whether jArtinM or rArtinM stimulation induced IL-2 production. At concentrations from 0.14 to $36 \mathrm{nM}$, jArtinM significantly increased IL-2 production by murine spleen cells, yielding a bell-shaped dose-response curve that was more discernible when cells were stimulated for $24 \mathrm{~h}$. Maximum IL-2 levels were determined with 2-9 nM jArtinM (Fig. 3a). Regarding the response to rArtinM, significant augmentation of IL-2 production was determined using 78-625 nM (Fig. 3b). Reaching peak IL-2 production required $4.5 \mathrm{nM}$ jArtinM and $156 \mathrm{nM}$ rArtinM. Therefore, a concentration of rArtinM 35 times higher than that of $\mathrm{jArtinM}$ was necessary to induce the highest levels of IL-2 production, which was close to that induced by $49 \mathrm{nM}$ ConA (positive control).

\section{Spleen cell proliferation induced by jArtinM and rArtinM}

Because both jArtinM and rArtinM stimulate mitochondrial activity of murine spleen cells and IL-2 production, we assayed their capacity to induce cell proliferative response through the $[3 \mathrm{H}]-\mathrm{TdR}$ incorporation assay. The doses of jArtinM and rArtinM that induced maximal mitochondrial activity and IL-2 production were chosen as the lectin concentrations to be assayed for cell proliferation induction. We used $2.25 \mathrm{nM}$ and $4.5 \mathrm{nM}$ jArtinM and $78 \mathrm{nM}$ and $156 \mathrm{nM}$ rArtinM. The two doses of both lectin preparations promoted spleen cell proliferation in levels closed to those determined by the positive control, $24.5 \mathrm{nM}$ ConA (Fig. 4).

Carbohydrate recognition in $\mathrm{jArtinM}$ and $\mathrm{rArtinM}$ stimulation of spleen cells

Because ArtinM CRD accounts for binding on spleen cells, we evaluated the role of carbohydrate recognition in cell activation induction. The fact that mitochondrial activity and IL-2 production were stimulated by jArtinM and ArtinM made these parameters suitable for sugar inhibition assays. The pre-incubation of $2.25 \mathrm{nM}$ jArtinM or $78.00 \mathrm{nM}$ rArtinM with $50 \mathrm{mM}$ Dmannose inhibited $80 \%$ of the mitochondrial activity induced 

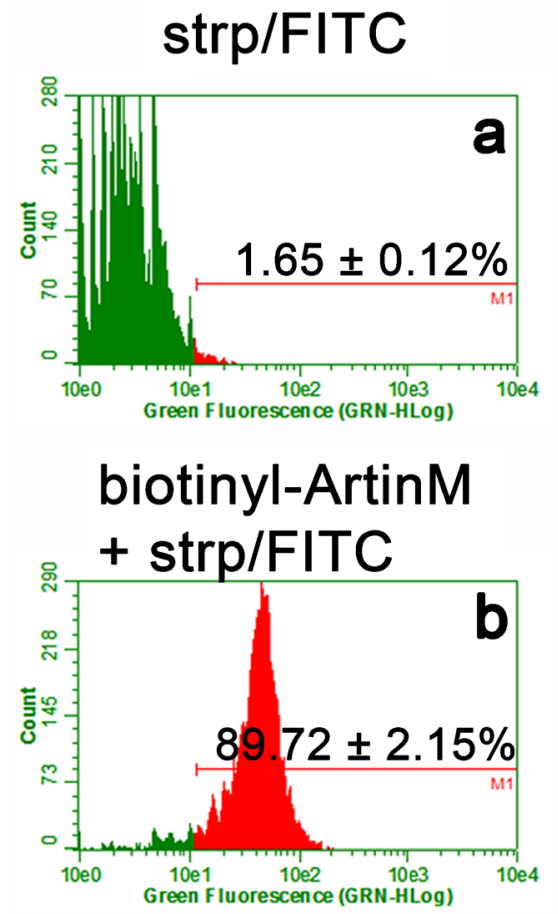
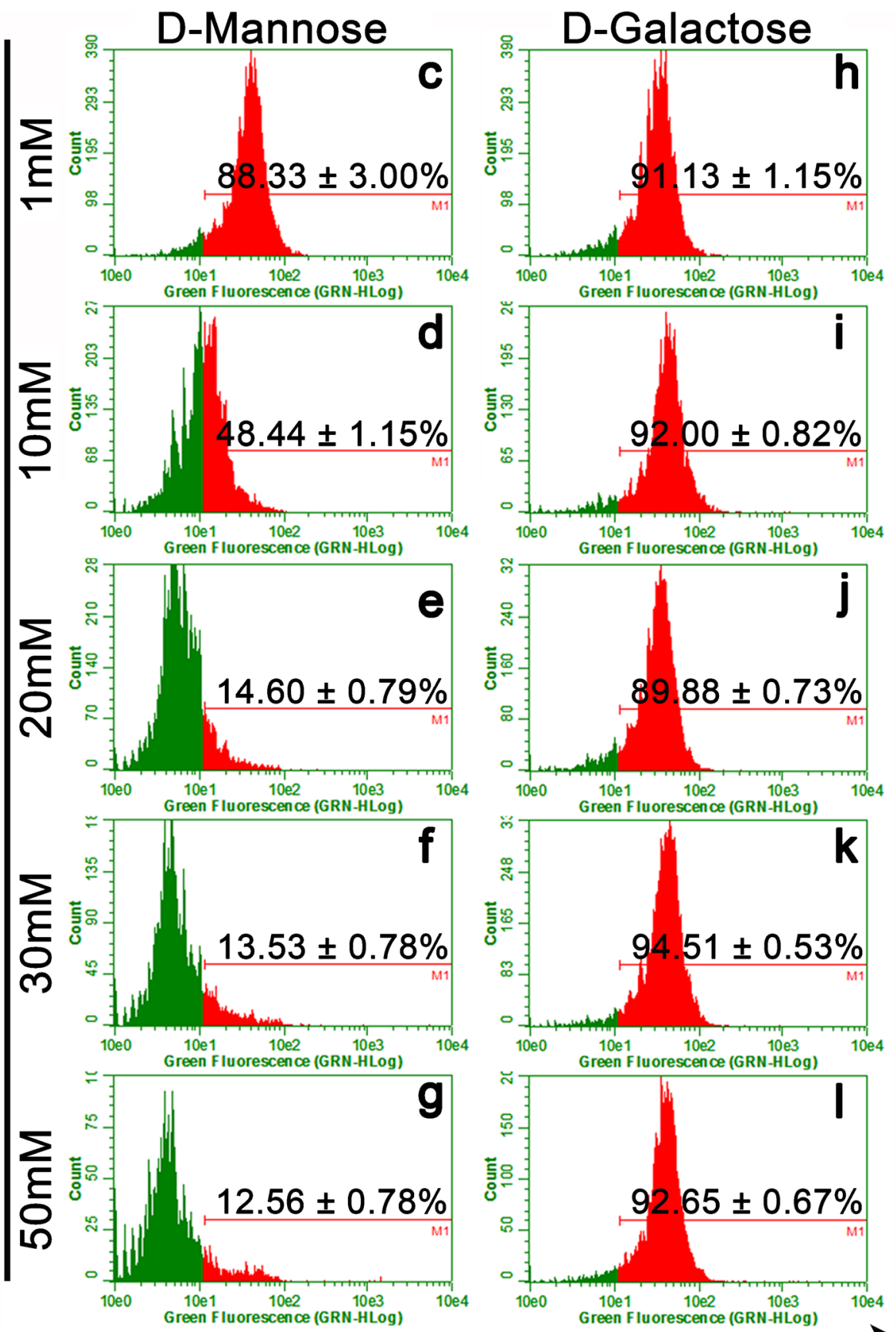

\section{biotinyl-ArtinM + strp/FITC}

Fig. 1 ArtinM binds to the surface of spleen cells through carbohydrate recognition. Biotinylated jArtinM $(20 \mu \mathrm{g} / \mathrm{mL})$ was incubated with the indicated concentrations of D-mannose $(\mathbf{c}-\mathbf{g})$ or D-galactose $(\mathbf{h}-\mathbf{l})$. The resulting mixtures were added to a suspension $\left(1.5 \times 10^{6}\right.$ cells $\left./ \mathrm{mL}\right)$ of fixed spleen cells, which were obtained from BALB/c mice. ArtinM binding was revealed by reaction with streptavidin-FITC $(5 \mu \mathrm{g} / \mathrm{mL})$.
Streptavidin-FITC alone was used as a negative control (a). The cells were washed and analyzed for fluorescence intensity by flow cytometry. Figures show the percentage of positive cells for ArtinM binding for each experimental condition (b-l). The results are expressed as means \pm SEM and represent 3 independent experiments by both ArtinM preparations and blocked the lectin property of inducing IL-2 production by spleen cells. Otherwise, Dmannose did not modify the activities of the positive control, which was PMA plus ionomycin. We also observed that pre- incubation of spleen cells with $50 \mathrm{mM}$ D-galactose had no effect on spleen cell activation induced by ArtinM. These results indicate that the jArtinM and rArtinM effects on spleen cells are mediated by sugar recognition (Fig. 5). 

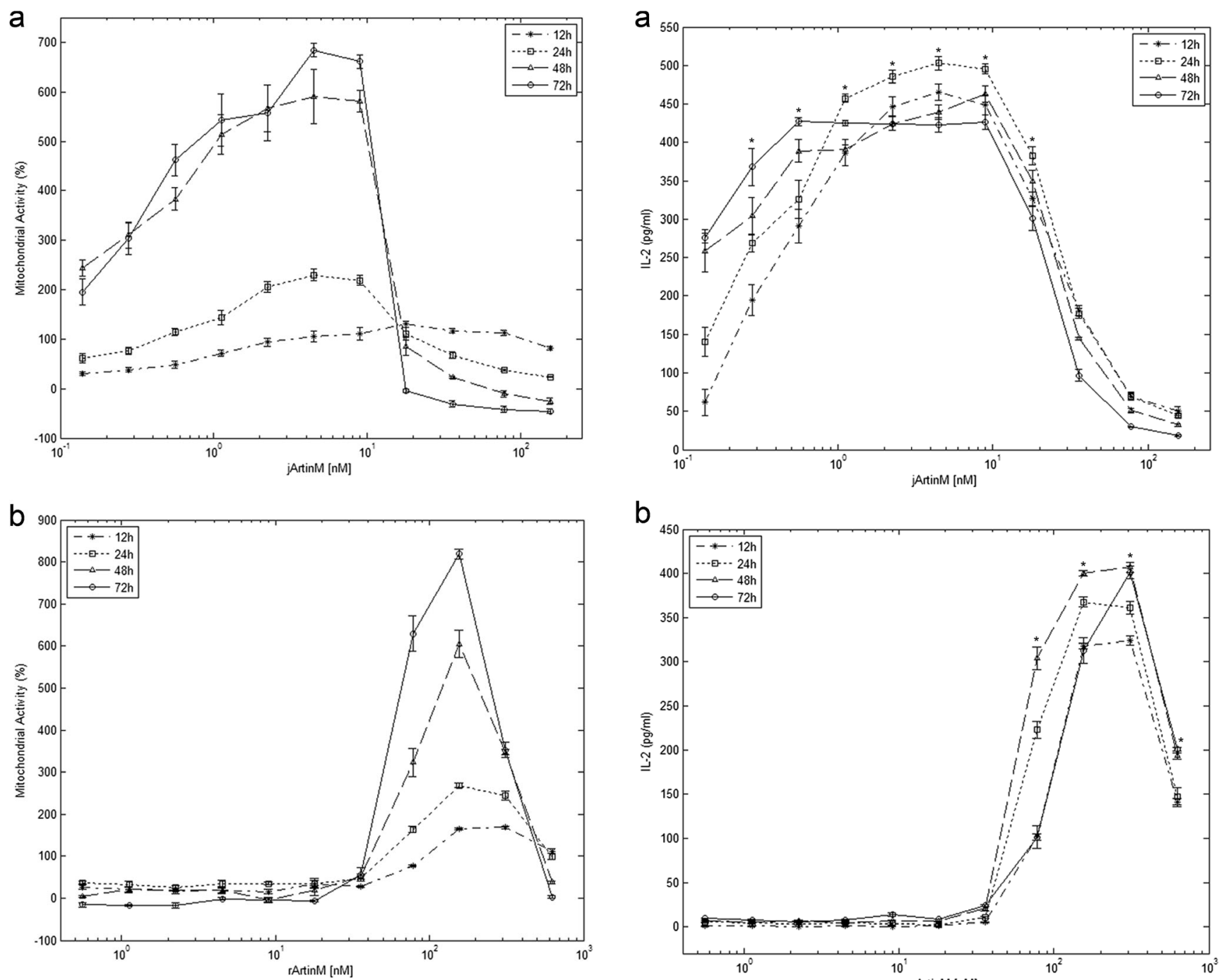

b

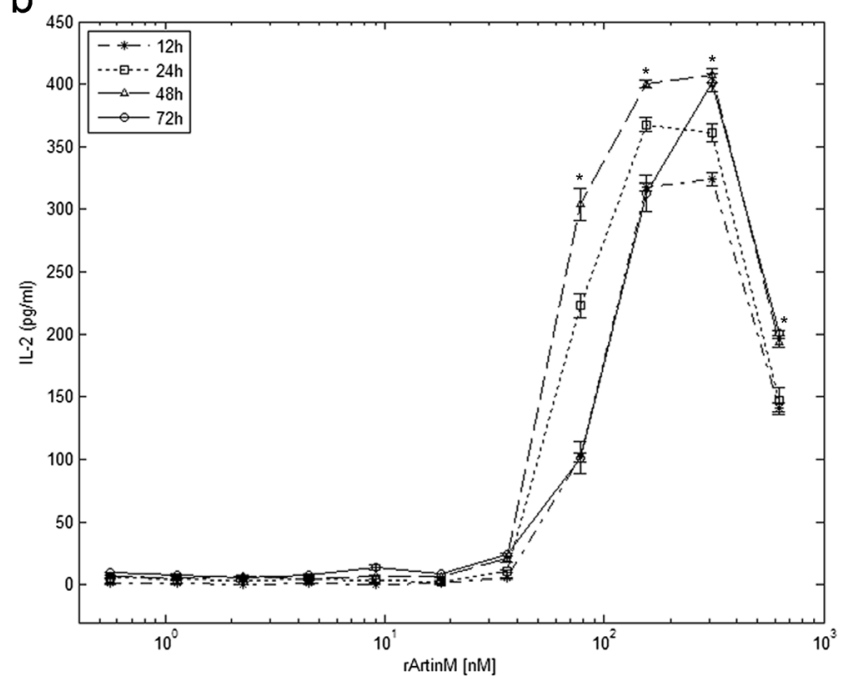

Fig. 2 ArtinM stimulates mitochondrial activity of spleen cells in a dosedependent manner. Murine spleen cells $\left(1.5 \times 10^{6}\right.$ cells $\left./ \mathrm{mL}\right)$ from BALB/c were distributed in 96-well microplates and incubated at $37{ }^{\circ} \mathrm{C}$ in a humidified atmosphere of $5 \% \mathrm{CO}_{2}$ and stimulated with jArtinM (a) or rArtinM (b) in concentrations of $0.14-156$ or $0.56-625 \mathrm{nM}$, respectively. Non-stimulated spleen cells were used as negative controls. After 12, 24, 48, and $72 \mathrm{~h}$ of incubation, 3-(4,5-dimethyl-thiazol-2-yl)-2,5-diphenyltetrazolium bromide (MTT) was added to the culture medium; MTT reduction to insoluble purple formazan dye crystals was detected via absorbance reading at $570 \mathrm{~nm}$. Mitochondrial activity was expressed as absorbance variation (in percentages) in relation to the negative control. Stimulation with Concanavalin A $(49 \mathrm{nM})$ was used as a positive control, which provided the following absorbance variations: $114.9 \pm 4.7(12 \mathrm{~h})$, $240.6 \pm 40.58$ ( $24 \mathrm{~h}), 852.7 \pm 22.41$ (48 h), and $704.6 \pm 15.3(72 \mathrm{~h})$. The results represent 3 independent experiments and are expressed as means \pm SEM

Spleen cell activation induced by ArtinM does not depend on TLR2 or TLR4

Since ArtinM recognizes glycans on TLR2, we investigated whether this interaction could account for the murine spleen cell activation. For this, we evaluated ArtinM-mediated stimulation of spleen cells isolated from TLR2 KO mice. Spleen

Fig. 3 ArtinM stimulates interleukin-2 (IL-2) production by spleen cells in a dose-dependent manner. Spleen cells $\left(1.5 \times 10^{6}\right.$ cells $\left./ \mathrm{mL}\right)$ from $\mathrm{BALB} / \mathrm{c}$ were distributed in 96 -well microplates and incubated at $37^{\circ} \mathrm{C}$ in a humidified atmosphere of $5 \% \mathrm{CO}_{2}$ and stimulated with jArtinM (a) or rArtinM (b) in concentrations of $0.14-156$ or $0.56-625 \mathrm{nM}$, respectively. After 12, 24, 48, and $72 \mathrm{~h}$ of incubation, the cell culture supernatants were analyzed for IL-2 levels with enzyme-linked immunosorbent assay. Stimulation with Concanavalin A $(49 \mathrm{nM})$, used as a positive control, provided the following IL-2 levels: $465.60 \pm 4.49$ (12 h), 495.8 \pm 7.06 ( $24 \mathrm{~h}), 421.6 \pm 4.37(48 \mathrm{~h})$, and $431.3 \pm 6.73(72 \mathrm{~h})$. Non-stimulated spleen cells, used as negative controls (medium), provided the following IL-2 levels: $10.11 \pm 2.04$ (12 h), 10.24 \pm 2.16 (24 h), 18.19 \pm 3.29 (48 h), and $31.59 \pm 4.49(72 \mathrm{~h})$. The results represent 3 independent experiments and are expressed as means \pm SEM. ${ }^{*} p<0.05$ compared to the medium for all incubation periods

cells from TLR4 KO mice were also examined to exclude the possibility of LPS contamination in the ArtinM preparations. Typically, spleen cells were stimulated for $24 \mathrm{~h}$ with jArtinM $(9 \mathrm{nM})$ or rArtinM $(312 \mathrm{nM})$, and were analyzed for mitochondrial activity as well as IL-2 production. Both analyses showed that ArtinM as well as ConA similarly activated spleen cells from WT and KO mice (Fig. 6). Mitochondrial 


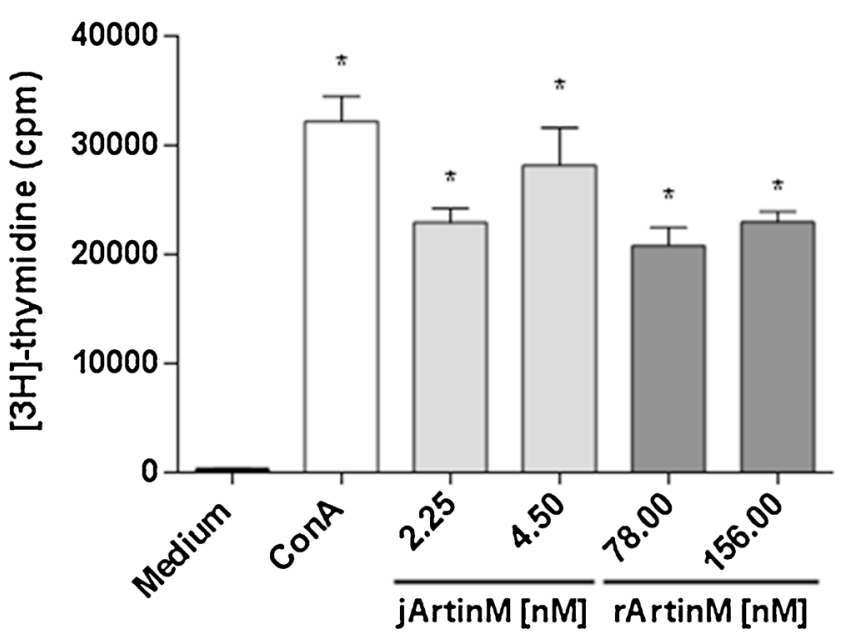

Fig. 4 Spleen cell proliferation induced by ArtinM. Spleen cells $(1.5 \times$ $10^{6}$ cells $/ \mathrm{mL}$ ) from BALB/c were distributed in a 96-well microplate and incubated for $48 \mathrm{~h}$ at $37^{\circ} \mathrm{C}$ in a humidified atmosphere with $5 \% \mathrm{CO}_{2}$ and stimulated with the indicated concentrations of jArtinM or rArtinM. Medium alone and Concanavalin A (ConA) $(24.5 \mathrm{nM})$ were used as negative and positive controls, respectively. After $36 \mathrm{~h}$ of stimulation, $[3 \mathrm{H}]$-thymidine $(0.5 \mu \mathrm{Ci} /$ well $)$ was added and measured for incorporation (cpm) after $12 \mathrm{~h}$ of incubation. The results are expressed as means $\pm \mathrm{SEM}$. *Significant differences with $p<0.05$ in relation to medium values

activity induced by LPS or Pam3Cys was absent in TLR4- or TLR2-deficient spleen cells, respectively. Since these agonists failed to induce IL-2 production after $24 \mathrm{~h}$, we conclude that TLR agonists and lectins induced spleen cells activation through distinct mechanisms.

Signaling molecules in jArtinM-and rArtinM-induced spleen cell activation

Considering that $\mathrm{jArtinM}$ and $\mathrm{rArtinM}$ have different oligomeric structures and induce spleen cell activation at distinct concentrations, we questioned whether they used the same or different signaling molecules to trigger the verified responses. Several pharmacological inhibitors (genistein, H-7, PD98059, SB202190, and SP600125) were then used to investigate the possible signaling molecules involved in responses to $2.25 \mathrm{nM}$ jArtinM or $78 \mathrm{nM}$ rArtinM. After $3 \mathrm{~h} 30 \mathrm{~min}$ of inhibitor treatment, cells were stimulated and analyzed for mitochondrial activity and IL-2 production. A similar profile of mitochondrial activity inhibition was associated with stimulation by jArtinM and rArtinM, showing that p38 MAPK, protein tyrosine kinase, and $\mathrm{JNK}$ are strongly involved in signaling triggered by both lectin preparations (Fig. 7a). Our results also demonstrated that IL-2 production was affected by protein tyrosine kinase inhibitor and JNK inhibitor (Fig. 7b) when stimulated by either jArtinM or rArtinM. Therefore, specific signaling molecules responsible for spleen cell activation were involved in the responses to both, native and recombinant ArtinM.

ArtinM binding on murine T cells

Considering that spleen cells encompass distinct cell populations that include $\mathrm{T}$ lymphocytes, we investigated whether ArtinM recognized $T$ cell glycans and induced the cell activation process observed when unseparated murine spleen cells were used. Through flow cytometry, we first analyzed jArtinM binding on spleen $\mathrm{CD}^{+}$cells. We verified that approximately $60 \%$ of the spleen cell suspension was stained for CD3. Among these anti-CD3 stained cells, 97\% were targeted by jArtinM; i.e., they were double-labeled for CD3 and jArtinM binding (Fig. 8). A proportion of $88 \%$ of the cell suspension was labeled with jArtinM, $48 \%$ of them corresponding to double-positive cells. These data indicate that $\mathrm{T}$ lymphocytes are targeted by $\mathrm{jArtinM}$ and are candidates to undergo the activation process induced by the lectin.

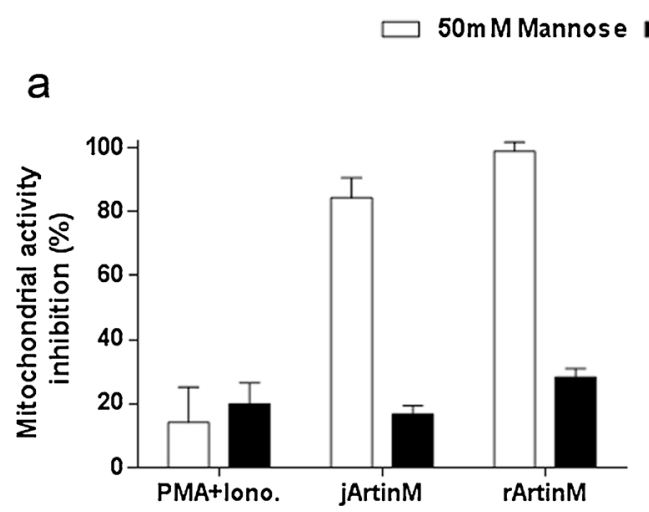

Fig. 5 Spleen cell activation by ArtinM depends on carbohydrate recognition. Murine spleen cells $\left(1.5 \times 10^{6}\right.$ cells $\left./ \mathrm{mL}\right)$ obtained from BALB/c were distributed in a 96-well microplate and incubated at $37{ }^{\circ} \mathrm{C}$ in a humidified atmosphere of $5 \% \mathrm{CO}_{2}$. The cells were stimulated with jArtinM (2.25 nM) or rArtinM (78.00 nM) and were previously incubated or not with $50 \mathrm{mM}$ D-mannose or D-galactose. Phorbol myristate acetate

$50 \mathrm{mM}$ Galactose

b

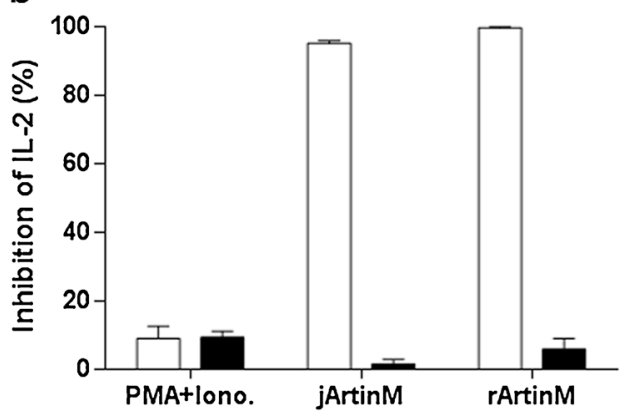

$(P M A ; 81 \mathrm{nM})$ plus ionomycin $(1 \mu \mathrm{M})$ was used as a positive control stimulus. After $48 \mathrm{~h}$ of stimulation, mitochondrial activity (a) and IL-2 production (b) were determined. The results are expressed as \% of inhibition, obtained by relating the measurements in the presence and absence of sugar for each stimulus. The results represent 3 independent experiments 


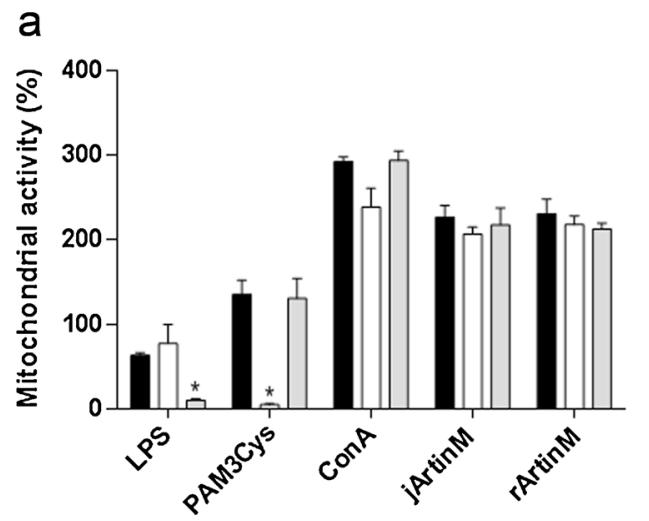

Fig. 6 TLR2 or TLR4 does not mediate spleen cell activation by ArtinM. Murine spleen cells $\left(1.5 \times 10^{6}\right.$ cells $\left./ \mathrm{mL}\right)$ from C57BL/6 (WT), TLR2 KO, and TLR4 $\mathrm{KO}$ mice were plated onto 96-well microplates, incubated at $37^{\circ} \mathrm{C}$ and $5 \% \mathrm{CO}_{2}$ in a humidified incubator, and stimulated for $24 \mathrm{~h}$ with $9 \mathrm{nM}$ jArtinM or $312 \mathrm{nM}$ rArtinM. Pam3Cys (TLR2 agonist, $1.5 \mu \mathrm{g} / \mathrm{mL}$ ), LPS (TLR4 agonist, $1 \mu \mathrm{g} / \mathrm{mL}$ ), or Concanavalin A (ConA) $(49 \mathrm{nM})$, were

\section{IL-2 production by $\mathrm{CD} 4^{+} \mathrm{T}$ cells stimulated by jArtinM and rArtinM}

Because lymphocyte activation is manifested by IL-2 production, and $\mathrm{CD}^{+} \mathrm{T}$ lymphocytes constitute a major IL-2 cell source, we assayed the effect of jArtinM and rArtinM stimulation on purified $\mathrm{CD}^{+} \mathrm{T}$ cells. After $48 \mathrm{~h}$ of incubation with 18,36 , or $78 \mathrm{nM} \mathrm{jArtinM}$ or 78,156 , or $312 \mathrm{nM}$ rArtinM, IL-2 production was induced in a dose-dependent manner. Figure 9 shows that similar levels of IL-2 were produced by $\mathrm{CD}^{+} \mathrm{T}$ cells stimulated with $36 \mathrm{nM}$ jArtinM or $312 \mathrm{nM}$ rArtinM, b

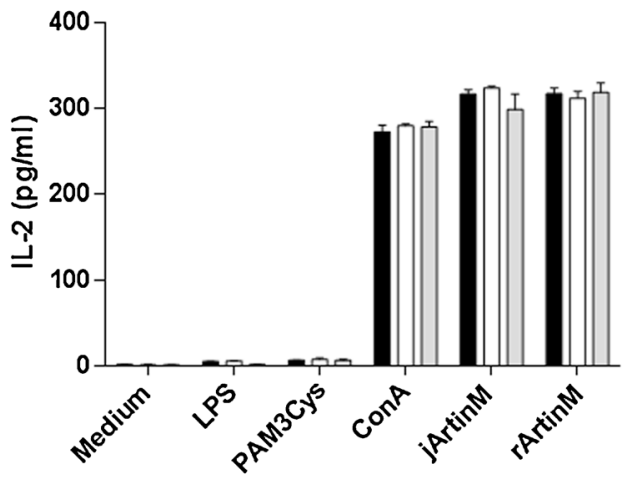

used as positive controls for stimulation, whereas the medium alone was used as negative control. Next, the cells were analyzed for mitochondrial activity (MTT assay) (a) and IL-2 production (ELISA method) (b). Results are expressed as means \pm SEM. $*$ Differences in response from that of $W T$ cells with $p<0.05$ was considered as significant

demonstrating that rArtinM is approximately ten times less effective than jArtinM for inducing lymphocyte activation.

\section{CD3 as a biologically relevant glycotarget of ArtinM}

The possibility that CD3 could be a glycotarget of ArtinM on $\mathrm{CD} 4^{+} \mathrm{T}$ cells was examined using an inhibition assay. Isolated $\mathrm{CD}^{+} \mathrm{T}$ cells, preincubated with or without ArtinM, were incubated with an anti-CD3 antibody. Flow cytometry analysis showed that ArtinM drastically inhibited the cell labeling with the anti-CD3 antibody (Fig. 10a-c). Because CD3 is

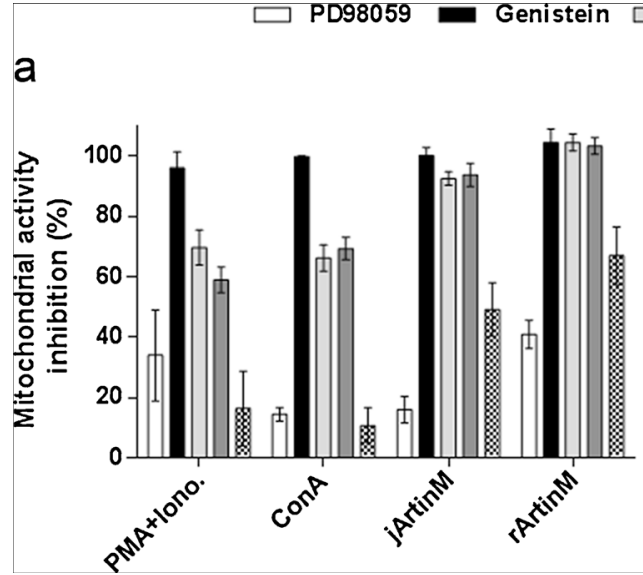

Fig. 7 Effect of inhibitor agents of molecules accounting for cell signaling pathways on jArtinM- or rArtinM-induced activation of spleen cells. PD98059 [p42/44 mitogen-associated protein kinase (MAPK) inhibitor; $20 \mu \mathrm{M}$ ], genistein (protein tyrosine kinase inhibitor; $20 \mu \mathrm{g} / \mathrm{mL}$ ), SB202190 (p38 MAPK inhibitor; $20 \mu \mathrm{M}$ ), SP600125 (c-Jun $N$-terminal kinase inhibitor; $25 \mu \mathrm{M}$ ), H-7 (protein kinase $\mathrm{C}$ inhibitor; $20 \mu \mathrm{M}$ ), or medium alone (absence of inhibitor) were used to pretreat, for $210 \mathrm{~min}$, murine spleen cells $\left(1.5 \times 10^{6} / \mathrm{mL}\right)$ that were distributed in 96 -well plates and maintained at $37{ }^{\circ} \mathrm{C}$ in a humidified atmosphere with $5 \% \mathrm{CO}_{2}$. After
SB202190 SP600125

b

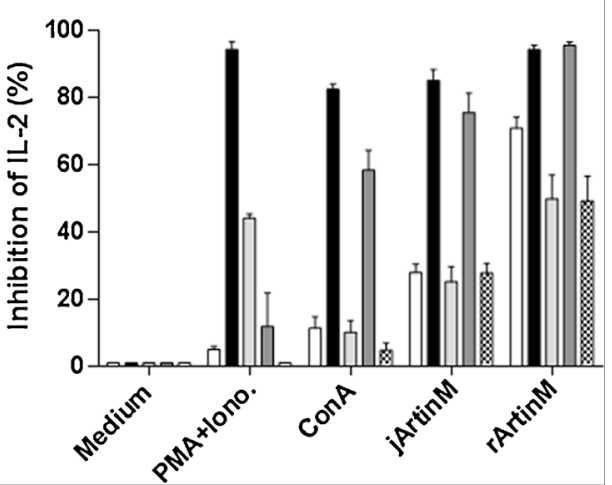

pretreatment, cells were stimulated with jArtinM $(2.25 \mathrm{nM})$ or rArtinM $(78 \mathrm{nM})$ for $48 \mathrm{~h}$. PMA $(81 \mathrm{nM})$ plus ionomycin $(1 \mu \mathrm{M})$ or Concanavalin A (ConA) (49 nM) were positive controls for cell stimulation, whereas medium alone provided the negative control. The cells were analyzed for mitochondrial activity via MTT assay (a) and IL-2 production via ELISA (b). Measurements are expressed as means \pm SEM, and the inhibition determined by each pharmacological agent was calculated by the ratio between the values obtained in the presence of a certain inhibitor and in its absence, represented by percentages 
Fig. 8 ArtinM binds to the surface of T lymphocytes. Spleen cells $\left(1.5 \times 10^{6} / \mathrm{ml}\right)$ were fixed and incubated for 40 min with antiCD3 PE-Cy5 antibody (4 $\mu \mathrm{g} / \mathrm{mL})$ (b, d). After washing, the cells were incubated for $40 \mathrm{~min}$ with biotinylated ArtinM $(15 \mu \mathrm{g} / \mathrm{mL})$ (c, d). ArtinM binding was revealed by reaction for $40 \mathrm{~min}$ with streptavidin-FITC (5 $\mu \mathrm{g}$ / $\mathrm{mL})$. Streptavidin-FITC and Isotype PE-Cy5 were used as a negative control (a). Cell fluorescence was analyzed with flow cytometry. Dot plots represent the percentage of positive cells obtained by biotinyl-ArtinM + strp/FITC or anti-CD3 PE-Cy5. The results are expressed as means $\pm \mathrm{SEM}$

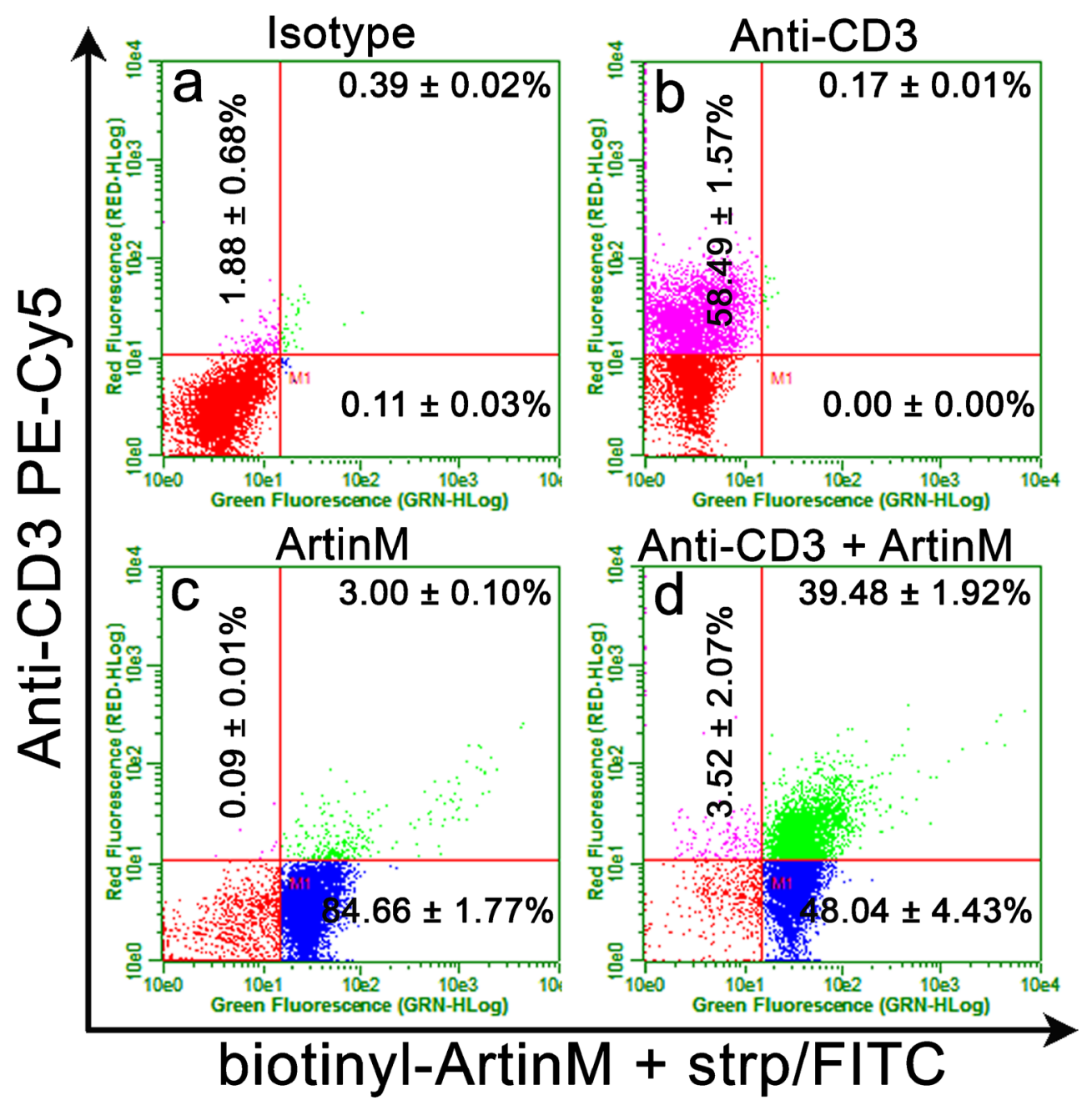

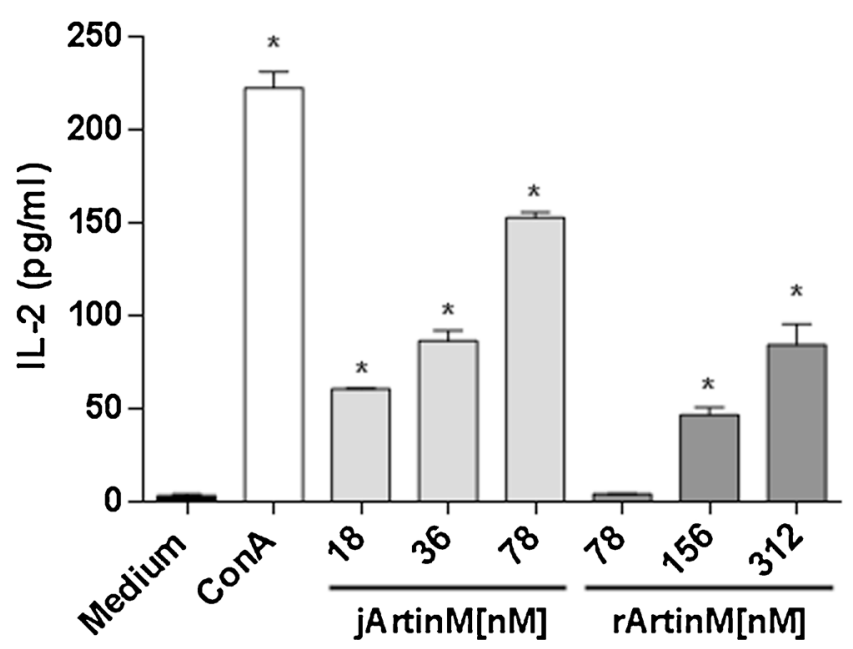

Fig. 9 jArtinM and rArtinM enhances IL-2 secretion in $\mathrm{CD}^{+} \mathrm{T}$ cells. Purified $\mathrm{CD}^{+} \mathrm{T}$ cells $\left(1 \times 10^{6}\right.$ cells $\left./ \mathrm{mL}\right)$ from a spleen cell suspension of $\mathrm{BALB} / \mathrm{c}$ mice were distributed in 96-well microplates and maintained at $37^{\circ} \mathrm{C}$ in a humidified atmosphere with $5 \% \mathrm{CO}_{2}$. The $\mathrm{CD} 4^{+} \mathrm{T}$ cells were stimulated for $48 \mathrm{~h}$ with jArtinM $(18,36$, or $78 \mathrm{nM})$ or $\operatorname{rArtinM}(78,156$, or $312 \mathrm{nM})$. Concanavalin A $(49 \mathrm{nM})$ was used as a positive control of stimulation. Culture supernatants were analyzed for IL-2 production using ELISA, and the results are expressed as means \pm SEM. *Significant differences when $p<0.05$ compared with medium values known to be functionally important for $\mathrm{T}$ cell activation, we tested the ability of the anti-CD3 antibody to block the ArtinM-induced activation of $\mathrm{CD} 4^{+} \mathrm{T}$ cells. The cells were preincubated with or without the anti-CD3 antibody and then stimulated with ArtinM. An IL-2 assay in culture supernatants showed that the anti-CD3 antibody inhibited the stimulatory effect of ArtinM on $\mathrm{CD}^{+}$T cells (Fig. 10d) and pointed to the functional relevance of $\mathrm{CD} 3$ as a glycotarget of ArtinM. A specific antibody against CD28, a costimulatory molecule that also participates in the activation of $\mathrm{T}$ lymphocytes, was unable to block the activation of $\mathrm{CD}^{+}{ }^{+} \mathrm{T}$ cells by ArtinM (Fig. 10d).

\section{Discussion}

The known ArtinM property of stimulating Th1 immunity in vivo has been attributed to lectin interaction with TLR2 $\mathrm{N}$-glycans on the surface of macrophages and dendritic cells. The present study is the first systemized effort to investigate the in vitro lectin effect on cells of adaptive immunity with the 

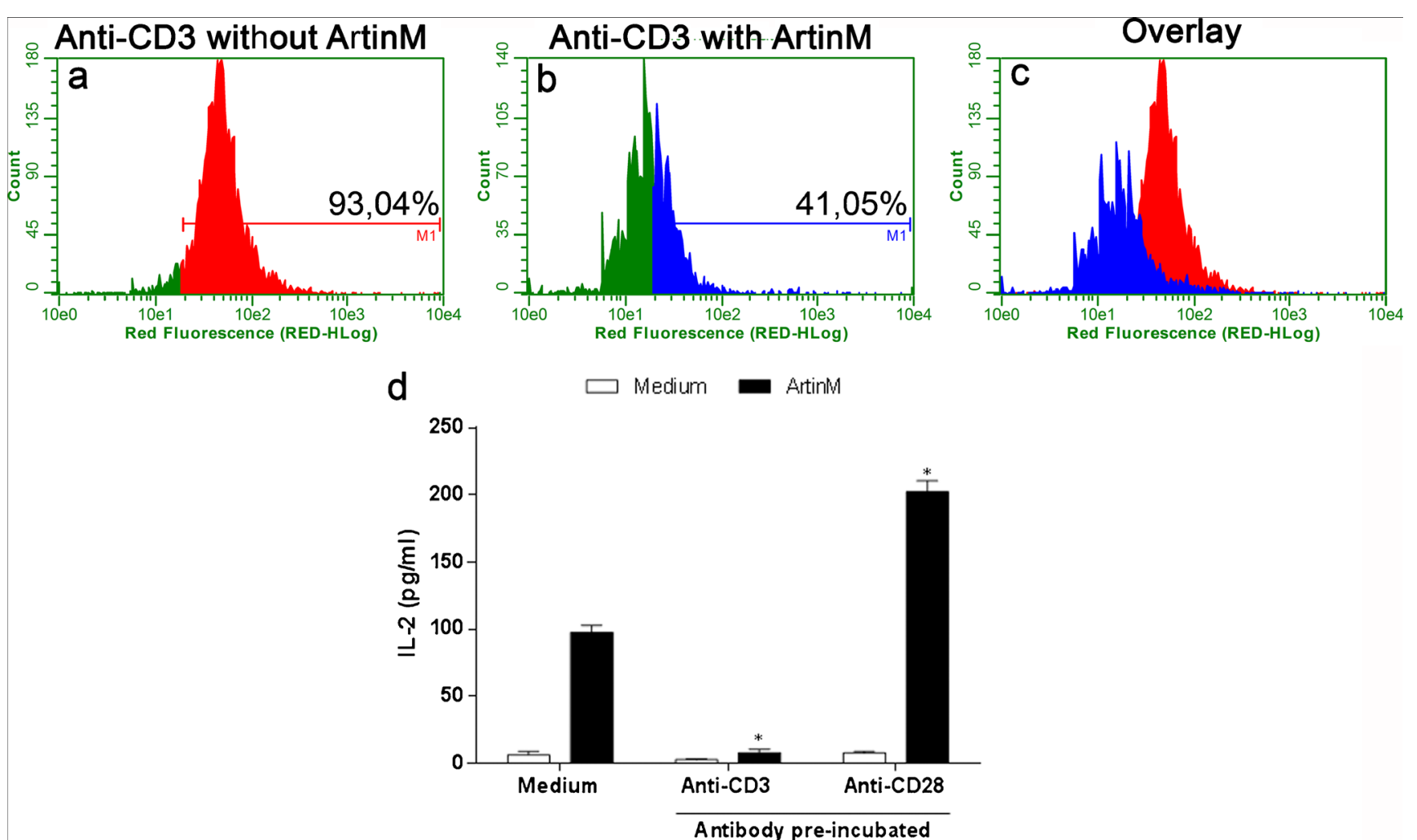

Fig. $10 \mathrm{CD} 3$ receptor as a glycotarget of ArtinM. (a-c) Purified CD4 ${ }^{+} \mathrm{T}$ cells $\left(1.5 \times 10^{6} / \mathrm{mL}\right)$ were fixed and incubated for 40 min with ArtinM $(25 \mu \mathrm{g} / \mathrm{mL})$. After washing, the cells were incubated for 40 min with an anti-CD3 PE-Cy5 antibody $(10 \mu \mathrm{g} / \mathrm{mL})$ and analyzed using flow cytometry. The histograms represent the percentage of cells positive for staining with the anti-CD3 PE-Cy5 antibody after preincubation with (b) or without (a) ArtinM. d Isolated CD4 $4^{+}$T cells $\left(1 \times 10^{6} / \mathrm{mL}\right)$ were incubated

assumption that it could contribute to the immuno modulation determined by ArtinM administration. By stimulating murine spleen cells, ArtinM induces cell activation, as manifested by increased mitochondrial activity, IL-2 production, and proliferation. These activities were shown to depend on carbohydrate recognition and involve glycotargets on surface $\mathrm{CD} 4^{+} \mathrm{T}$ cells.

The lymphoproliferative properties of plant lectins have been reported extensively since the discovery that phytohemagglutinin (PHA) from Phaseolus vulgaris (Nowell 1960), pokeweed mitogen from Phytolacca americana (Farnes et al. 1964), and concanavalinA from Canavalia ensiformis (Wecksler et al. 1968) stimulate lymphocytes to undergo mitosis. The application of mitogenic lectins as tools in biomedical research gained force when PHA-activated human lymphocytes were shown to secrete a T cell growth factor, now known as IL-2. Subsequently, activated immune cells were shown to produce many other factors, now collectively denoted as cytokines.

It is well established that lymphocyte activation by lectins is initiated via binding to cell surface sugars, a fact verified here for ArtinM and reinforcing a previous observation by with the anti-CD3 antibody $(5 \mu \mathrm{g} / \mathrm{mL})$ or an anti-CD28 antibody $(5 \mu \mathrm{g} /$ $\mathrm{mL})$ for $40 \mathrm{~min}$ and then stimulated with ArtinM $(78 \mathrm{nM})$ for $48 \mathrm{~h}$. IL-2 concentration in the culture supernatants was quantified by means of ELISA, and the results are expressed as mean \pm SEM; ${ }^{*} p<0.05$ compared to the cells that were preincubated with vehicle (culture medium) and then stimulated with ArtinM

Benoist et al. (2009). We showed that the lectin binds on the surface of non-separated spleen cells as well as on isolated $\mathrm{CD} 4^{+} \mathrm{T}$ cells in a manner that depends on carbohydrate recognition, because D-mannose selectively inhibited ArtinM binding to the cell surface. Our preliminary results showed that ArtinM binds to Jurkat cells through carbohydrate recognition (data not shown), as has been demonstrated for Jacalin (Baba et al. 2007). Additional studies are underway to analyze the mitogenic and/or cytotoxic effects of jArtinM and rArtinM on human cells.

Clearly, binding to appropriately glycosylated receptors is insufficient to stimulate lymphocytes. Mitogenic lectins set in motion a signal transduction pathway that also functions on the antigen-dependent activation of lymphocytes. The key event in this pathway is protein tyrosine kinase activation, which mediates interactions with adapter proteins in a process that allows the enzymatic hydrolysis of phosphatidylinositol 4,5-biphosphate into diacylglycerol and inositol 1,4,5-triphosphate, both of which act as $\mathrm{Ca}^{++}$-dependent second messengers. Subsequently, the activation of two major pathways that involve Ras and protein kinase $\mathrm{C}$ results in the activation of MAPKs and extracellular signal-regulated kinases 1 and 2 . 
The concerted action of the signal amplification triggers biochemical processes that result in the production and release of IL-2 (Smith-Garvin et al. 2009). Using inhibitors of signaling molecules, we showed that the increased mitochondrial activity and IL-2 production induced by ArtinM depend on the signaling molecules mentioned above. Additional experiments using purified $\mathrm{T}$ cells are necessary to further analyze and demonstrate the involvement of these molecules.

Mitogenicity of ArtinM on human PBMC were focused on the very first reports of ArtinM biological properties (de Miranda-Santos et al. 1991). Subsequent studies were primarily motivated by the discovery that ArtinM administration confers resistance against $L$. major infection in $\mathrm{BALB} / \mathrm{c}$ mice (Panunto-Castelo et al. 2001). The studies demonstrated that ArtinM directly stimulates antigen-presenting cells to produce IL-12, providing an apparently full rational basis for ArtinM application as an efficient immunomodulatory agent. Although mandatory, evaluation of the ArtinM direct effect on cells of the adaptive immunity has been withdrawn. Indeed, correlation between the properties of several plant lectins of stimulating IL-12 production and inducing lymph proliferation has been examined previously and showed that only wheat germ agglutinin of Triticum vulgare induced IL-12 production without promoting cell proliferation or IL-2 release (Muraille et al. 1999). Here, we demonstrate that ArtinM-induced proliferation of murine spleen cells is independent of TLR2. Most of the lectins assayed by Muraille et al. (1999), and now verified for ArtinM, have been shown to stimulate both lymphocyte proliferation and IL-12 production, suggesting that they recognize specific oligosaccharides on the surface of the cells involved in adaptative and innate immunity.

The sugar-binding specificity of lectins is due to a limited segment of conserved amino acid residues that constitute their CRD (Drickamer 1988; Sharon and Lis 2004). An appropriate CRD structure is required from recombinant lectins to reproduce the sugar specificity of their native counterparts. This requirement was satisfied by $\mathrm{rArtinM}$, as verified by glycoarray studies (Pranchevicius et al. 2012) and reinforced by the similar kinetic rates and affinity equilibrium constants provided by the interaction of $\mathrm{jArtinM}$ and $\mathrm{rArtinM}$ with $\mathrm{N}$ glycans of horseradish peroxidase glycoprotein (Pesquero et al. 2010). However, they differ in terms of avidity owing to diversity in their tertiary structures: $\mathrm{jArtinM}$ is organized as a tetramer, whereas rArtinM is monomeric (Pranchevicius et al. 2012). Nonetheless, these features are insufficient to explain the distinct concentrations required of jArtinM and rArtinM to activate spleen cells. The quotients between the concentrations required to induce mitochondrial activity, IL-2 production, and cell proliferation are much higher $(>30)$ than that between the number of CRDs per jArtinM and rArtinM molecule (=4). Regardless, these preparations stimulated the same responses on spleen cells, and in vivo administration of
rArtinM was as effective as $\mathrm{jArtinM}$ in conferring protection against $P$. brasiliensis (Coltri et al. 2008). We hypothesized that ArtinM tetramer, as a multivalent ligand, has superior efficiency owing to a greater capability to cluster receptors on the cell surface in a process that optimizes the triggered cell signaling, as reported for $\mathrm{T}$ cell receptor (TCR) containing microclusters that generate and sustain T-cell activation (Yokosuka et al. 2005).

To characterize the mechanisms of immunomodulation induced by external agents, we must investigate the effect they exert on immune cell populations. The various $\mathrm{T} \mathrm{CD} 4^{+}$ effector/regulatory subpopulations deserve special attention. Naive $\mathrm{CD}^{+} \mathrm{T}$ cells may differentiate into any of several lineages of Th cells (Th1, Th2, and Th17) or into induced regulatory T cells. Th1 cells make interferon- $\gamma$ as a signature cytokine and are also IL-2 producers; in addition, IL-12, mostly produced by antigen-presenting and natural killer cells, plays a central role in Th1 differentiation (Zhu and Paul 2010). In the case of ArtinM induced-Th1 immunity, the stimulus of IL-12 production has been thoroughly examined. The present study suggests that the Th1 immunity (known to be induced in vivo by ArtinM) involves ArtinM's direct effects on differentiation of naive $\mathrm{CD}^{+}{ }^{+} \mathrm{T}$ cells into the $\mathrm{Th} 1$ lineage. This is because lectin binds to $\mathrm{CD} 4^{+} \mathrm{T}$ cells and induces IL- 2 production. This idea is reinforced by the observation that jArtinM induces IFN- $\gamma$ production by $\mathrm{CD}^{+} \mathrm{T}$ cells (data not shown). Moreover, the mechanism of $\mathrm{CD}^{+}{ }^{+} \mathrm{T}$-cell activation by ArtinM involves interaction with $\mathrm{CD} 3$, which was shown to be a functionally relevant glycotarget of ArtinM in the process of activation of the lymphocytes. Although our results do not rule out participation of other ArtinM glycotargets in driving the activation of $\mathrm{CD}^{+} \mathrm{T}$ cells, we can state that $\mathrm{CD} 3$ is an essential participant because its blockage with a specific antibody inhibited the response to ArtinM by more than $90 \%$.

In summary, our study shows that ArtinM binding to murine spleen cells is followed by increased proliferation, mitochondrial activity, and IL-2 production in a carbohydrate recognition-dependent manner. $\mathrm{CD}^{+}{ }^{+} \mathrm{T}$ cells are clearly targeted by the lectin, providing a direct mechanism of inducing Th1 immunity. It is added to the indirect mechanism provided by ArtinM targeting of antigen-presenting cells, which accounts for increased IL-12 production and stimulation of Th1 differentiation. This double Th1 stimulation may decisively contribute to the efficiency of the in vivo immunomodulation induced by ArtinM administration. The present work opens new perspectives in understanding the full mechanism of immunomodulation induced by carbohydrate recognition.

Acknowledgments We thank Fernanda C. Carvalho, Rafael R. Azevedo and Ramiro R. A. Barreira for helpful discussions. We also thank Sandra M.O. Thomaz, Patricia E. Vendruscolo, and Érica 
Vendruscolo for technical support, and Domingos Soares de Souza Filho for expert animal care. This research was financially supported by Fundação de Amparo a Pesquisa do Estado de São Paulo (grant numbers 2006/60642-2, 2010/51763-6 and 2012/09611-0), Conselho Nacional de Desenvolvimento Científico e Tecnológico (306503/2009-3), Financiadora de Estudos e Projetos (0110045900), Coordenação de Aperfeiçoamento de Pessoal de Nível Superior and Fundação de Apoio ao Ensino, Pesquisa e Assistência do Hospital das Clínicas da Faculdade de Medicina de Ribeirão Preto.

Open Access This article is distributed under the terms of the Creative Commons Attribution License which permits any use, distribution, and reproduction in any medium, provided the original author(s) and the source are credited.

\section{References}

Baba M, Yong Ma B, Nonaka M, Matsuishi Y, Hirano M, Nakamura N, Kawasaki N, Kawasaki T (2007) Glycosylation-dependent interaction of Jacalin with CD45 induces $\mathrm{T}$ lymphocyte activation and Th1/Th2 cytokine secretion. J Leukoc Biol 81:1002-1011

Benoist H, Culerrier R, Poiroux G, Segui B, Jauneau A, Van Damme EJ, Peumans WJ, Barre A, Rouge P (2009) Two structurally identical mannose-specific jacalin-related lectins display different effects on human T lymphocyte activation and cell death. J Leukoc Biol 86: $103-114$

Cardoso MR, Mota CM, Ribeiro DP, Santiago FM, Carvalho JV, Araujo EC, Silva NM, Mineo TW, Roque-Barreira MC, Mineo JR, Silva DA (2011) ArtinM, a D-mannose-binding lectin from Artocarpus integrifolia, plays a potent adjuvant and immuno stimulatory role in immunization against Neospora caninum. Vaccine 29:9183-9193

Coltri KC, Oliveira LL, Pinzan CF, Vendruscolo PE, Martinez R, Goldman MH, Panunto-Castelo A, Roque-Barreira MC (2008) Therapeutic administration of $\mathrm{KM}+$ lectin protects mice against Paracoccidioides brasiliensis infection via interleukin-12 production in a toll-like receptor 2-dependent mechanism. Am J Pathol 173:423-432

Coltri KC, Oliveira LL, Ruas LP, Vendruscolo PE, Goldman MH, Panunto-Castelo A, Roque-Barreira MC (2010) Protection against Paracoccidioides brasiliensis infection conferred by the prophylactic administration of native and recombinant ArtinM. Med Mycol 48:792-799

Custodio LA, Loyola W, Conchon-Costa I, da Silva Quirino GF, Felipe I (2011) Protective effect of ArtinM from extract of Artocarpus integrifolia seeds by Th1 and Th17 immune response on the course of infection by Candida albicans. Int Immunopharmacol 11:15101515

daSilva LL, de Molfetta-Machado JB, Panunto-Castelo A, Denecke J, Goldman GH, Roque-Barreira MC, Goldman MH (2005) cDNA cloning and functional expression of $\mathrm{KM}+$ the mannose-binding lectin from Artocarpus integrifolia seeds. Biochim Biophys Acta 1726:251-260

de Miranda-Santos IK, Mengel JOJ, Bunn-Moreno MM, Campos-Neto A (1991) Activation of T and B cells by a crude extract of Artocarpus integrifolia is mediated by a lectin distinct from jacalin. J Immunol Methods 140:197-203
Drickamer K (1988) Two distinct classes of carbohydrate-recognition domains in animal lectins. J Biol Chem 263:9557-9560

Farnes P, Barker BE, Brownhill LE, Fanger H (1964) Mitogenic activity in Phytolacca americana (pokeweed). Lancet 2:1100-1101

Ganiko L, Martins AR, Espreafico EM, Roque-Barreira MC (1998) Neutrophil haptotaxis induced by the lectin $\mathrm{KM}+$. Glycoconj $\mathrm{J} 15$ : $527-530$

Moreno AN, Jamur MC, Oliver C, Roque-Barreira MC (2003) Mast cell degranulation induced by lectins: effect on neutrophil recruitment. Int Arch Allergy Immunol 132:221-230

Mosmann T (1983) Rapid colorimetric assay for cellular growth and survival: application to proliferation and cytotoxicity assays. J Immunol Methods 65:55-63

Muraille E, Pajak B, Urbain J, Leo O (1999) Carbohydrate-bearing cell surface receptors involved in innate immunity: interleukin-12 induction by mitogenic and nonmitogenic lectins. Cell Immunol 191:1-9

Nowell PC (1960) Phytohemagglutinin: an initiator of mitosis in cultures of normal human leukocytes. Cancer Res 20:462-466

Panunto-Castelo A, Souza MA, Roque-Barreira MC, Silva JS (2001) KM $(+)$, a lectin from Artocarpus integrifolia, induces IL-12 p40 production by macrophages and switches from type 2 to type 1 cellmediated immunity against Leishmania major antigens, resulting in BALB/c mice resistance to infection. Glycobiology 11:1035-1042

Pereira-da-Silva G, Moreno AN, Marques F, Oliver C, Jamur MC, Panunto-Castelo A, Roque-Barreira MC (2006) Neutrophil activation induced by the lectin $\mathrm{KM}+$ involves binding to CXCR2. Biochim Biophys Acta 1760:86-94

Pesquero NC, Pedroso MM, Watanabe AM, Goldman MH, Faria RC, Roque-Barreira MC, Bueno PR (2010) Real-time monitoring and kinetic parameter estimation of the affinity interaction of $j A$ rtinM and $\mathrm{rArtinM}$ with peroxidase glycoprotein by the electro gravimetric technique. Biosens Bioelectron 26:36-42

Peumans WJ, Van Damme EJ (1995) Lectins as plant defense proteins. Plant Physiol 109:347-352

Pranchevicius MC, Oliveira LL, Rosa JC, Avanci NC, Quiapim AC, Roque-Barreira MC, Goldman MH (2012) Characterization and optimization of ArtinM lectin expression in Escherichia coli. BMC Biotechnol 12:44

Santos-de-Oliveira R, Dias-Baruffi M, Thomaz SM, Beltramini LM, Roque-Barreira MC (1994) A neutrophil migration-inducing lectin from Artocarpus integrifolia. J Immunol 153:1798-1807

Sharon N (2008) Lectins: past, present and future. Biochem Soc Trans 36: $1457-1460$

Sharon N, Lis H (2004) History of lectins: from hemagglutinins to biological recognition molecules. Glycobiology 14:53R-62R

Smith-Garvin JE, Koretzky GA, Jordan MS (2009) T cell activation. Annu Rev Immunol 27:591-619

Teixeira CR, Cavassani KA, Gomes RB, Teixeira MJ, Roque-Barreira MC, Cavada BS, da Silva JS, Barral A, Barral-Netto M (2006) Potential of $\mathrm{KM}+$ lectin in immunization against Leishmania amazonensis infection. Vaccine 24:3001-3008

Wecksler M, Levy A, Jaffe WG (1968) Mitogenic effects of extracts of canavalia ensiformis and Concanavalina A. Acta Cient Venez 19: 154-156

Yokosuka T, Sakata-Sogawa K, Kobayashi W, Hiroshima M, HashimotoTane A, Tokunaga M, Dustin ML, Saito T (2005) Newly generated $\mathrm{T}$ cell receptor microclusters initiate and sustain $\mathrm{T}$ cell activation by recruitment of Zap70 and SLP-76. Nat Immunol 6:1253-1262

Zhu J, Paul WE (2010) Heterogeneity and plasticity of T helper cells. Cell Res 20:4-12 